\title{
Assessment of Pteridophyte Diversity and their Status in Gujarat State, Western India
}

\author{
Kishore S. Rajput ${ }^{1}$, Ronak N. Kachhiyapatel ${ }^{1}$, Suresh K. Patel ${ }^{2}$ and Vinay M. Raole ${ }^{1}$ \\ ${ }^{1}$ Department of Botany, Faculty of Science, The Maharaja Sayajirao University of Baroda, Vadodara-390002, Gujarat, India \\ ${ }^{2}$ Department of Botany, Government Science College, Gandhinagar, Gujarat, India
}

\section{Article history}

Received: 07 May 2016

Accepted: 07 September 2016

Published: 1 October 2016

(c) Rajput et al. (2016)

Editor

K. K. Sabu

\section{Publisher}

Horizon e-Publishing Group

Corresponding Author

Kishore S. Rajput

\ks.rajput15@yahoo.com

\begin{abstract}
An intensive field survey was carried out from the hilly regions, plains of different climatic regimes and agricultural land of Gujarat state. About 23 species were collected from Gujarat state, from which eight species viz., Actiniopteris radiata (Sw.) Link, Adiantum caudatum L., A. incisum Forssk., Lygodium flexuosum (L.) Sw., Pteris vittata L., Selaginella ciliaris (Retz.) Spring, S. delicatula (Desv. ex Poir.) Alston, and S. repanda (Desv. ex Poir.) Spring. were added as new distributional record for the Gujarat state. Increasing anthropogenic pressure, destruction of forest ecosystem and development of infrastructure facilities including road widening and rainwater harvesting program by deepening of the natural ponds are additional reasons for declining terrestrial and aquatic pteridophyte diversity respectively. Our survey concludes that E. debile is regionally extinct in the wild while Isoetes coromandeliana, will be lost from its natural habitat in short time if not conserved properly. Therefore, there is an urgent need of in situ conservation by developing action plans in collaboration with the state forest department.
\end{abstract}

Keywords

Diversity of Pteridophytes; Distribution; Gujarat state

Rajput, K. S., R. N. Kachhiyapatel, S. K. Patel and V. M. Raole. 2016. Assessment of Pteridophyte Diversity and their Status in Gujarat State, Western India. Plant Science Today 3(4): 337-348. http://dx.doi.org/10.14719/pst.2016.3.3.235

\section{Introduction}

Pteridophytes are the considered one of the early land dwellers and most primitive group of vascular plants that appeared on this planet in the midPalaeozoic era (i.e. approx. 438 million years ago) during the Silurian period (Dudani et al., 2011, 2014). Their adaptation to terrestrial condition by evolving specialized tissues for the translocation of water and food is responsible for their greater colonization in terrestrial ecosystems. Development of vascular tissue not only contributed in water and food translocation but also played crucial role in mechanical support. Therefore, many of them such as Cyathea and Wilsonia (tree ferns) could attain great heights like trees. This interesting group of plants form an important component of forest ecosystem and act as connecting bridge between the non-vascular cryptogams and the seed plants and occupy various niches on the land, in marshes, swamps and in water bodies (Dudani et al. 2011). They flourish in moist tropical and temperate forests while, they also occur in different eco-geographical regions of the world where the conditions are not conducive for growth (Dixit, 2000). The majority of them thrive well in shady and moist places but a few survive in rock crevices and dry places while some of them such as Salvinia and Azolla grow in aquatic habitats (Bower, 1923, 1963). 
According to Smith et al. (2006), it is estimated that there are about $9000-15000$ species of pteridophytes that occur throughout the world while Moran (2008) predicted it to be approximately 13,600 species. Due to diversified topography, variable climatic conditions and geographical position, about 1200 species of pteridophytes are reported from India (Dixit, 1984, 2000; Sukumaran et al., 2009; Dudani et al., 2011; Patil and Dongare, 2013, Kavitha et al., 2015; Kachhiyapatel et al., 2015; Patel et al.. 2015; Patil et al., 2012, 2014, 2016; Rajput et al., 2016), in which nearly 17\% species are endemic (Sanjappa and Venu, 2010). However, similar studies are lacking on the diversity of the state of Gujarat.

First report on pteridophyte (Ceratopteris thalictroides) of Gujarat comes from the Flora of North Gujarat written by Saxton and Sedgwick (1918). Subsequent studies on pteridophyte of Gujarat were taken up by contemporary researchers such as Phatak et al. (1953), Chavan and Mehta (1956), Gaekwad and Deshmukh (1956), Chavan and Sabnis (1961), Chavan and Padate (1962, 1963), Mahabale (1948, 1963), Shah and Vaidya (1964), Nayar and Devi (1964), Padate (1969), Inamdar and Shah (1967) and Inamdar (1970). Gujarat Ecological Commission (1996) documented 16 species of pteridophytes from different parts of the state, including forest areas. Thereafter, this group of plants was completely neglected and studies on them lagged behind. However, recently few sporadic reports about the occurrence of pteridophyte have been carried out by Patel et al. (2010), Dabgar (2012), and Modi and Dudani (2013). However, these reports lack location specific data on species reported from the state. This emphasizes the necessity for in-depth inventorization and documentation of pteridophytes. Thus, it was thought worthwhile to study the diversity of pteridophytes from Gujarat state.

\section{Materials and Methods}

The field survey was carried out from Gujarat state during different seasons of the year 2013 to 2015 . Field photographs were taken by using digital camera (Cannon SLR 1200D). The collected specimens were properly processed in laboratory for the preparation of herbariums (Bridson and Forman, 1992). The herbariums have been deposited in the BARO herbarium of the Department of Botany, Faculty of Science, the Maharaja Sayajirao University of Baroda, Vadodara, Gujarat (India). Identification of specimens was carried out by the help of various flora viz., Beddome (1883), Blatter and d'Almeida (1922), Dixit (1984), Khullar (1994, 2000), Ghosh et al. (2004), Fraser-Jenkins (2008), Chandra (2000), Kholia (2014) and Fraser-Jenkins et al. (2015). After identification and verification of correct identity, further confirmation of identity was done by Dr. Sachin Patil from Department of Botany, Shivaji
University Kolhapur (Maharashtra state). The classification of families and genera is followed according to Fraser-Jenkins (2009).

Information on the distribution pattern of pteridophytes in Gujarat is data deficient. However, on the basis of our last three years extensive survey in different regions and discussion with the field taxonomist, their status is categorized in the present study into RET species by following the guidelines for application of IUCN red list criteria at regional and national level (Version $3.12^{\text {nd }}$ Edition and Version 12, http://www.iucnredlist.org/documents/RedListGuid elines.pdf).

\section{Result and Discussion}

The present comprehensive survey of Gujarat state records 23 (22 in wild and one under cultivation) species belonging to 11 families and 15 genera of pteridophytes (Table 1). Most number of species were observed in Pteridaceae $(7$ species), Ophioglossaceae (5 species) and Selaginellaceae (3 species) while Equisetaceae, Isoetaceae, Lygodiaceae, Azollaceae, Marsileaceae, Salviniaceae, Dryopteridaceae and Woodsiaceae represents one species. Amongst these species of pteridophytes, maximum diversity was found in Dang (forest) District, Shoolpaneshwar wildlife sanctuary (Narmada district) and Wilson hills in Dharampur district of the state. In the present study about 08 species viz., Actiniopteris radiata (from Chotila, Than, Pavagadh, Chotta Udaipur and common in most part of the North Gujarat), Adiantum caudatum (frequently observed in most of the forest regions throughout the state), $A$. incisum (commonly observed in most of the forests throughout the state), Lygodium flexuosum presently observed throughout south Gujarat but expected in other parts), Pteris vittata (presently observed on the banks of major rivers and in rock crevices of south Gujarat forest and expected more in other parts), Selaginella ciliaris, $S$. delicatula and $S$. repanda (at several places in south Gujarat, Narmada district and expected other forests also) were added as new distributional record for the Gujarat state (Fig. 1-4). Some of the specimens collected from different forest regions were found to be biotypes of Ophioglossum (Fig. 5). Biotypes are the specimens that differ in size or shape of the particular organ like fronds or whole plant however they are identical in physiology physiological and anatomical characteristics (Anonymous, 2003-2015). Panigrahi and Dixit (1967) and Goswami (2007) reported occurrence of biotypes in the genus Ophioglossum. In the present study, we also noticed several variations in size of the specimen or number of tropophylls. The species viz., Ophioglossum costatum, $O$. reticulatum and $O$. nudicaule are most common species for Gujarat state and the species viz. Isoetes coromandeliana, Lygodium flexuosum, Ophioglossum gramineum and Tectaria coadunata 
Table 1: List of species reported by earlier workers and in the present study. Abbreviations: $\mathrm{T}=$ Terrestrial, $\mathrm{L}=\mathrm{Lithophyte}$, $\mathrm{A}=$ Aquatic and UC= Under Cultivation. Threat status as per regional level IUCN criteria: REW= Regionally Extinct in the Wild, $\mathrm{CE}=$ Critically Endangered, EN= Endangered, LC = Least Concerned, DD= Data Deficient. \# may be typographical error in species name.* Species reported by earlier researchers with other name, which is synonym at present, ${ }^{* *}$ Identification remains restricted up to genera level only.

\begin{tabular}{|c|c|c|c|c|c|c|}
\hline $\begin{array}{l}\text { Sr. } \\
\text { No. }\end{array}$ & Name of Species & Family & Habit & Localities & $\begin{array}{l}\text { IUCN category } \\
\text { (Local threats, if } \\
\text { any?) }\end{array}$ & References \\
\hline 1 & Actiniopteris australis & Pteridaceae & $\mathrm{L}$ & Hampheswar, Kavant & Not seen in field & GEC (1996) \\
\hline 2 & Actiniopteris radiata & Pteridaceae & $\mathrm{L}$ & $\begin{array}{l}\text { Ambaji, Balaram, Chotila, Chotta } \\
\text { Udaipur, Jambughoda, Jessore, } \\
\text { Junaraj, Pavagadh, Polo Forest, } \\
\text { Than, Zarwani }\end{array}$ & LC & Newly reported \\
\hline \multirow{2}{*}{3} & \multirow{2}{*}{$\begin{array}{l}\text { * Adiantum philippense } \\
\text { (syn. A. lunulatum) }\end{array}$} & \multirow{2}{*}{ Pteridaceae } & \multirow{2}{*}{$\mathrm{T}, \mathrm{L}$} & Kavant, Navsari, Sagai, Vansda & \multirow{2}{*}{ LC } & GEC (1996) \\
\hline & & & & Common in all Forest & & Present study \\
\hline 4 & Adiantum caudatum & Pteridaceae & T, L & Common in all Forest & LC & Newly reported \\
\hline 5 & Adiantum incisum & Pteridaceae & T, L & Common in all Forest & LC & Newly reported \\
\hline 6 & $\begin{array}{l}\text { \# Aleuritopteris- } \\
\text { favinosa } \\
\text { (Probably A. farinosa) }\end{array}$ & Pteridaceae & $\mathrm{L}$ & Kavant & $\begin{array}{l}\text { Probably A. bicolor } \\
\text { (common in all } \\
\text { forests) }\end{array}$ & GEC (1996) \\
\hline 7 & $\begin{array}{l}\text { * Aleuritopteris bicolor } \\
\text { (syn: A. farinosa) }\end{array}$ & Pteridaceae & $\mathrm{L}$ & $\begin{array}{l}\text { Dharampur, Don, Junagadh, Jun- } \\
\text { araj, Mahal, Sagai, Saputara, } \\
\text { Vansda, Vavar, Zarwani, Dab- } \\
\text { khal (Common in all forest) }\end{array}$ & LC & $\begin{array}{l}\text { Kachhiyapatelet al. } \\
\text { (2015), } \\
\text { Present study }\end{array}$ \\
\hline 8 & Athyrium solenopteris & Woodsiaceae & $\mathrm{T}, \mathrm{L}$ & Girnar, Saurastra & $\begin{array}{l}\text { Not seen in the } \\
\text { Field, } \\
\text { DD }\end{array}$ & Nayar and Devi (1964) \\
\hline 9 & $\begin{array}{l}\text { Athyrium hohenackeri- } \\
\text { anum }\end{array}$ & Woodsiaceae & $\mathrm{T}, \mathrm{L}$ & $\begin{array}{l}\text { Dharampur, Don, Junaraj, Ma- } \\
\text { hal, Sagai, Saputara, Vansda, } \\
\text { Vavar, Zarwani, Dabkhal (Com- } \\
\text { mon in all forest) }\end{array}$ & LC & $\begin{array}{l}\text { Kachhiyapatel et al. } \\
\text { (2015), Present study }\end{array}$ \\
\hline \multirow[t]{2}{*}{10} & \multirow[t]{2}{*}{$\begin{array}{l}\text { Azolla pinnata subsp. } \\
\text { asiatica }\end{array}$} & \multirow[t]{2}{*}{ Azollaceae } & \multirow[t]{2}{*}{ A } & $\begin{array}{l}\text { Ahmedabad, Dabhoi, Kavant, } \\
\text { Savli, Tuwa, Vadodara }\end{array}$ & \multirow[t]{2}{*}{$\mathrm{LC}$} & $\begin{array}{l}\text { Chavan and Sabnis } \\
\text { (1961), Chavan and Pad- } \\
\text { ate (1962), GEC (1996), } \\
\text { Dabgar (2012), Modi } \\
\text { and Dudani (2013) } \\
\end{array}$ \\
\hline & & & & $\begin{array}{l}\text { Common in wetlands through- } \\
\text { out the state }\end{array}$ & & Present study \\
\hline 11 & $\begin{array}{l}\text { Ceratopteris thalic- } \\
\text { troides }\end{array}$ & Pteridaceae & A & $\begin{array}{l}\text { Dharampur, Junagadh, Khed- } \\
\text { brahma, Navsari, Rajpipla, } \\
\text { Ratanmahal, Sabarmati river, } \\
\text { Savli, Tuwa, Vansda, Vyara, Vat- } \\
\text { rak river }\end{array}$ & LC & $\begin{array}{l}\text { Saxton and Sedgwick } \\
\text { (1918), Mahabale (1948, } \\
\text { 1963), Chavan and Pad- } \\
\text { ate (1962, 1963), Padate } \\
\text { (1969), GEC (1996) }\end{array}$ \\
\hline
\end{tabular}

Dediapada), Panjara ghat (N.

Dediapada), Rajpipla (Khunta

Present study amba), Vansda

$12{ }^{* *}$ Cheilanthes sp. Pteridaceae L Vansda $\quad \begin{gathered}\text { Probably Aleuritop- } \\ \text { teris bicolor (due to } \\ \text { common occur- } \\ \text { rence in all forests) }\end{gathered}$

13 Equisetum debile Equisetaceae UC Savli
MSU Botanical Garden (1962), Padate (1969),

$\begin{array}{ll} & \text { Presently under cultivation in } \\ \text { MSU Botanical Garden }\end{array}$

REW $\quad$ Patel et al. 2015 and

\begin{tabular}{|c|c|c|c|c|c|c|}
\hline 14 & $\begin{array}{l}\text { Isoetes coromandeli- } \\
\text { ana }\end{array}$ & Isoetaceae & A & $\begin{array}{l}\text { Talod, Tuwa, Vadodara, } \\
\text { Vaktapur (Nr. Gandhinagar) }\end{array}$ & $\mathrm{CE}$ & $\begin{array}{l}\text { mukh (1956), Chavan } \\
\text { and Sabnis (1961), GEC } \\
\text { (1996), Patel et al. } \\
\text { (2015), Dixit (1984) and } \\
\text { Present study }\end{array}$ \\
\hline 15 & **Lygodium sp. & Lygodiaceae & $\mathrm{T}$ & Vansda & $\begin{array}{l}\text { Probably } L \text {. } \\
\text { flexuosum }\end{array}$ & GEC (1996) \\
\hline 16 & Lygodium flexuosum & Lygodiaceae & $\mathrm{T}$ & $\begin{array}{l}\text { Chavshala (Nr. Kaprada), } \\
\text { Dhulda, Mahal, Ratanmahal, } \\
\text { Vansda, Wilson Hill }\end{array}$ & EN & Newly reported \\
\hline 17 & $\begin{array}{l}{ }^{*} \text { Marsilea minuta } \\
\text { (syn: } \text { M. quadrifolia) }\end{array}$ & Marsileaceae & A & $\begin{array}{l}\text { Ahmedabad, Borsad, Dabhoi, } \\
\text { Fulsar, Kavant, Navsari, Savli, } \\
\text { Vadodara }\end{array}$ & LC & $\begin{array}{l}\text { Chavan and Sabnis } \\
\text { (1961), Chavan and Pad- } \\
\text { ate (1962), GEC (1996), } \\
\text { Patel et al. (2010), }\end{array}$ \\
\hline
\end{tabular}




\begin{tabular}{|c|c|c|c|c|c|c|}
\hline & & & & & & $\begin{array}{l}\text { Dabgar (2012), Modi } \\
\text { and Dudani (2013) }\end{array}$ \\
\hline & & & & $\begin{array}{l}\text { Throughout the state in ponds, } \\
\text { rivers and dams etc. }\end{array}$ & & Present Study \\
\hline \multirow[b]{2}{*}{18} & \multirow[b]{2}{*}{$\begin{array}{l}{ }^{*} \text { Ophioglossum cost- } \\
\text { atum (syn: } O . \text { fibrosum) }\end{array}$} & \multirow[b]{2}{*}{$\begin{array}{l}\text { Ophio- } \\
\text { glossaceae }\end{array}$} & \multirow[b]{2}{*}{$\mathrm{T}$} & Dharampur, Kavant, Vadodara & \multirow[b]{2}{*}{$\mathrm{LC}$} & $\begin{array}{l}\text { Phatak et al. (1953), In- } \\
\text { amdar (1970), GEC } \\
\text { (1996) }\end{array}$ \\
\hline & & & & $\begin{array}{l}\text { Ahwa, Chinchli, Dang, Don, } \\
\text { Hathnimata, Jambughoda, Jun- } \\
\text { agadh, Junaraj, Malegaon, Polo } \\
\text { Forest, Ratanmahal, Sagai, } \\
\text { Vansda, Wilson hills, Zandhanu- } \\
\text { man, Zarwani }\end{array}$ & & Present study \\
\hline \multirow[b]{2}{*}{19} & \multirow[b]{2}{*}{$\begin{array}{l}\text { Ophioglossum reticu- } \\
\text { latum }\end{array}$} & \multirow[b]{2}{*}{$\begin{array}{l}\text { Ophio- } \\
\text { glossaceae }\end{array}$} & \multirow[b]{2}{*}{$\mathrm{T}, \mathrm{L}$} & Dang & \multirow[b]{2}{*}{$\mathrm{LC}$} & $\begin{array}{l}\text { Phatak et al. (1953), } \\
\text { Shah and Vaidya (1964) }\end{array}$ \\
\hline & & & & $\begin{array}{l}\text { Ahwa, Chinchli, Dang, Dharam- } \\
\text { pur, Don, Hathnimata, Jambug- } \\
\text { hoda, Junagadh, Junaraj, Mahal, } \\
\text { Malegaon, Polo forest, Ratanma- } \\
\text { hal, Sagai, Vansda, Zand Hanu- } \\
\text { man, Zarwani }\end{array}$ & & Present study \\
\hline \multirow{2}{*}{20} & \multirow{2}{*}{$\begin{array}{l}\text { Ophioglossum } \\
\text { gramineum }\end{array}$} & \multirow{2}{*}{$\begin{array}{l}\text { Ophio- } \\
\text { glossaceae }\end{array}$} & \multirow{2}{*}{$\mathrm{T}$} & Vadodara & \multirow{2}{*}{$\mathrm{CE}$} & $\begin{array}{l}\text { Chavan and Mehta } \\
\text { (1956) }\end{array}$ \\
\hline & & & & Jambughoda, Zand Hanuman & & $\begin{array}{l}\text { Rajput et al. (2016), } \\
\text { Present study }\end{array}$ \\
\hline \multirow[b]{2}{*}{21} & \multirow[b]{2}{*}{$\begin{array}{l}\text { Ophioglossum nudi- } \\
\text { caule }\end{array}$} & \multirow[b]{2}{*}{$\begin{array}{l}\text { Ophio- } \\
\text { glossaceae }\end{array}$} & \multirow[b]{2}{*}{$\mathrm{T}$} & Dharampur, Tuwa & \multirow[b]{2}{*}{$\mathrm{LC}$} & $\begin{array}{l}\text { Phataket al. (1953), In- } \\
\text { amdar and Shah (1967), } \\
\text { Inamdar (1970), GEC } \\
\text { (1996), Dixit (1984) }\end{array}$ \\
\hline & & & & $\begin{array}{l}\text { Ahwa, Chinchli, Dang, Don, } \\
\text { Hathnimata, Jambughoda, Jun- } \\
\text { agadh, Junaraj, Malegaon, Polo } \\
\text { forest, Ratanmahal, Sagai, } \\
\text { Vansda, Wilson hills, Zand } \\
\text { Hanuman, Zarwani }\end{array}$ & & Present study \\
\hline 22 & **Ophioglossum spp. & $\begin{array}{l}\text { Ophio- } \\
\text { glossaceae }\end{array}$ & $\mathrm{T}$ & Vansda & $\begin{array}{l}\text { Probably } O . \text { cost- } \\
\text { atum } \\
\text { (due to its common } \\
\text { occurrence in all } \\
\text { forests) }\end{array}$ & GEC (1996) \\
\hline 23 & $\begin{array}{l}\text { Ophioglossum vul- } \\
\text { gatum }\end{array}$ & $\begin{array}{l}\text { Ophio- } \\
\text { glossaceae }\end{array}$ & $\mathrm{T}$ & Vadodara & Not seen in field & Phatak et al. (1953) \\
\hline 24 & $\begin{array}{l}\text { *Ophioglossum parvi- } \\
\text { folium (syn. O. nudi- } \\
\text { caule var. macrorrhi- } \\
\text { zum) }\end{array}$ & $\begin{array}{l}\text { Ophio- } \\
\text { glossaceae }\end{array}$ & $\mathrm{T}$ & $\begin{array}{l}\text { Dharampur forest, Hathnimata, } \\
\text { Junaraj, Mahal, Polo forest, } \\
\text { Sagai, Wilson hills, Zand Hanu- } \\
\text { man, Zarwani }\end{array}$ & $\mathrm{LC}$ & $\begin{array}{l}\text { Inamdar and Shah } \\
\text { (1967), Inamdar (1970) } \\
\text { and Dixit (1984), Kach- } \\
\text { hiyapatel et al. (2015), } \\
\text { Present study }\end{array}$ \\
\hline 25 & $\begin{array}{l}\text { Pteris vittata (reported } \\
\text { in wild) }\end{array}$ & Pteridaceae & $\mathrm{T}, \mathrm{L}$ & $\begin{array}{l}\text { Ahwa, Dhulda, Don, Kaprada, } \\
\text { Vansda, Waghai, Wilson hills }\end{array}$ & $\mathrm{LC}$ & Newly reported \\
\hline 26 & Salvinia molesta & Salviniaceae & $\mathrm{A}$ & Ghuntvel, Vadodara,Waghai & $\mathrm{LC}$ & $\begin{array}{l}\text { Kachhiyapatel et al. } \\
\text { (2015), Present study }\end{array}$ \\
\hline 27 & **Selaginella spp. & $\begin{array}{l}\text { Selaginel- } \\
\text { laceae }\end{array}$ & $\mathrm{T}, \mathrm{L}$ & Kavant, Ninai ghat, Vansda & $\begin{array}{c}\text { Probably S. ciliaris } \\
\text { (due to its common } \\
\text { occurrence in all } \\
\text { forests) }\end{array}$ & GEC (1996) \\
\hline 28 & Selaginella ciliaris & $\begin{array}{l}\text { Selaginel- } \\
\text { laceae }\end{array}$ & $\mathrm{T}, \mathrm{L}$ & $\begin{array}{l}\text { Ahwa, Dharampur, Kaprada, } \\
\text { Mahal, Narmada, Sagai, Vansda, } \\
\text { Wilson hills (common in all } \\
\text { forest) }\end{array}$ & $\mathrm{LC}$ & Newly reported \\
\hline 29 & Selaginella delicatula & $\begin{array}{l}\text { Selaginel- } \\
\text { laceae }\end{array}$ & $\mathrm{T}, \mathrm{L}$ & $\begin{array}{l}\text { Ahwa, Junaraj, Kaprada, Mahal, } \\
\text { Sagai, Vansda, Wilson hills, Zar- } \\
\text { wani }\end{array}$ & $\mathrm{LC}$ & Newly reported \\
\hline 30 & Selaginella repanda & $\begin{array}{l}\text { Selaginel- } \\
\text { laceae }\end{array}$ & $\mathrm{T}, \mathrm{L}$ & $\begin{array}{l}\text { Ahwa, Dharampur, Junaraj, } \\
\text { Kaprada, Karjan Dam, Mahal, } \\
\text { Malegaon, Saputara, Vansda, } \\
\text { Waghai, Wilson hills, Zarwani }\end{array}$ & LC & Newly reported \\
\hline 31 & Tectaria coadunata & $\begin{array}{l}\text { Dryopter- } \\
\text { idaceae }\end{array}$ & $\mathrm{T}, \mathrm{L}$ & $\begin{array}{l}\text { Chinchli, Don, Junaraj, } \\
\text { Malegaon, Saputara, Zarwani }\end{array}$ & EN & $\begin{array}{l}\text { Kachhiyapatel et al. } \\
\text { (2015), Present study }\end{array}$ \\
\hline 32 & Tectaria cicutaria & $\begin{array}{l}\text { Dryopter- } \\
\text { idaceae }\end{array}$ & $\mathrm{T}, \mathrm{L}$ & Girnar, Saurastra & $\begin{array}{l}\text { Not seen in the } \\
\text { field }\end{array}$ & Nayar and Devi (1964) \\
\hline
\end{tabular}


falls under RET category (Table 1). However, Equisetum debile, is regionally extinct in the wild while few saplings are under cultivation in the botanical garden of the Maharaja Sayajirao University of Baroda.

Earlier researchers reported 16 species of pteridophytes in wild, which represents a very poor status of pteridophyte diversity in the state (GEC, 1996, Modi, 2015). However from these 16 species, they identified four specimens only up to the generic level while other five species are the synonyms as per recent nomenclatural changes. During the present survey, most of the species were collected by us from the same or different localities as reported by earlier workers. However, we failed to recollect Isoetes coromandeliana and Equisetum debile from the reported localities. Both I. coromandeliana and E. debile lost their previously recorded habitat due to the urbanization and developmental policies such as road widening, water harvesting programs or habitat destruction due to deforestation and anthropogenic activities. Perusal of literature indicates that Isoetes coromandeliana at Harni (Gaekwad and Deshmukh, 1956, Chavan and Sabnis, 1961 and GEC, 1996) and E. debile at Savali (Chavan and Padate, 1962, Padate, 1969 and GEC, 1996) were commonly available in the aquatic pockets. Nevertheless, these localities are now converted into housing colonies as a suburban area of the Vadodara city. Thereafter, authors of the present study relocated this species from Talod and Vaktapur (Patel et al., 2015). Similarly, Ophioglossum gramineum was recorded by Chavan and Mehta (1956) from Harni village that has been now completely replaced with residential colonies and housing societies which resulted in loss of habitat forever. Nayar and Devi (1964) also documented Tectaria cicutaria from Girnar and other parts of Saurastra and Athyrium solenopteris from Girnar forest (Saurashtra region) of Gujarat. Chavan and Padate (1962), and Padate (1969), reported Equisetum debile from only one location i.e. Savli. Patel et al. (2015) worked on this species; however they could not found the same in wild after several visits on the same location, which indicates its extinction from its natural habitat. According to earlier reports, that Pteris vittata is cultivated as ornamental but in the present study we collected it growing wild in deep forest of Ahwa, Don, Waghai, Vansda, Kaprada forest and Wilson hills. It is also under cultivation throughout the state as ornamental in gardens as well as indoor plant. In 1996, Gujarat Ecological Commission (GEC) compiled pteridophyte diversity of Gujarat state and enlisted about 16 species belonging to 12 genera. We succeeded in the collection of all the species (excluding synonymous species and Equisetum debile) either from the same or another (new) location from the state (Table 1). The species viz., Marsilea quadrifolia, Aleuritopteris farinosa, Ophioglossum fibrosum, $O$. nudicaule var. macrorrhizum and Adiantum lunulatum that are reported by earlier researches are synonym to Marsilea minuta, Aleuritopteris bicolor, Ophioglossum costatum, O. parvifolium and Adiantum philippense respectively.

Pteridophytes are plenty in the tropical, sub-tropical and moist deciduous forests of India. However, due to large scale destruction of forests has extremely affected the diversity of pteridophyte flora throughout the country. They flourish well in thick forests and their life-cycle depends upon the quality of forests. In the race of technology development and development of infrastructure facilities and anthropogenic pressure led to habitat destruction, which is consequently resulted in reduction in forest cover and destruction of natural habitat of many plant species. Several species of them are now rare or on the verge of extinction (Fraser-Jenkins, 2012). Based on the field observations, herbarium collections and available secondary data from the literature, Chandra et al. (2008), and FraserJenkins, assessed the status of rare and threatened pteridophytes of India and Asia respectively. According to proposed list of Chandra et al., Ophioglossum gramineum and Isoetes coromandeliana falls under the category of endangered species. Recently, Fraser-Jenkins updated the status of pteridophyte and above said both the species are documented as "near threatened" species in Asian continents. After consulting local residents of Talod and Vaktapur, it is observed that population of I. coromandeliana has drastically decreased within last two years because of deepening of the water pond under rain water harvesting program.

According to guidelines of IUCN, red list categories (IUCN 2001, 2012, 2016) may be used unaltered at regional level except three categories viz. taxa regionally extinct (RE) i.e. taxa extinct within region but existing in other region, Extinct in Wild (EW) i.e. extinct in natural habitat but they are under cultivation and Not Applicable (NA) i.e. introduced taxa which are not eligible for assessment at regional level. Beside these categories, there are other possible categories to access the taxa regionally. These categories are as follows: Critically endangered (CR), Endangered (EN), Vulnerable (VU), Near threatened (NT), Least concern (LC), Data deficient (DD), Not evaluated (NE). Since, there are no studies on diversity of pteridophytes of Gujarat, their status falls under Data deficient (DD) or Not evaluated (NE). In the present study, we have kept those taxa in the Least concern (LE) category which are abundantly available in the forest areas while other genera which are either available in other areas but authors have not collected from that locality are kept in DD while species like $O$. gramineum and $I$. coromandeliana are extensively surveyed but found only at one or two locations respectively. As per IUCN guidelines (for regional level assessment), $O$. gramineum and $I$. coromandeliana fall under CE category and Lygodium flexuosum 

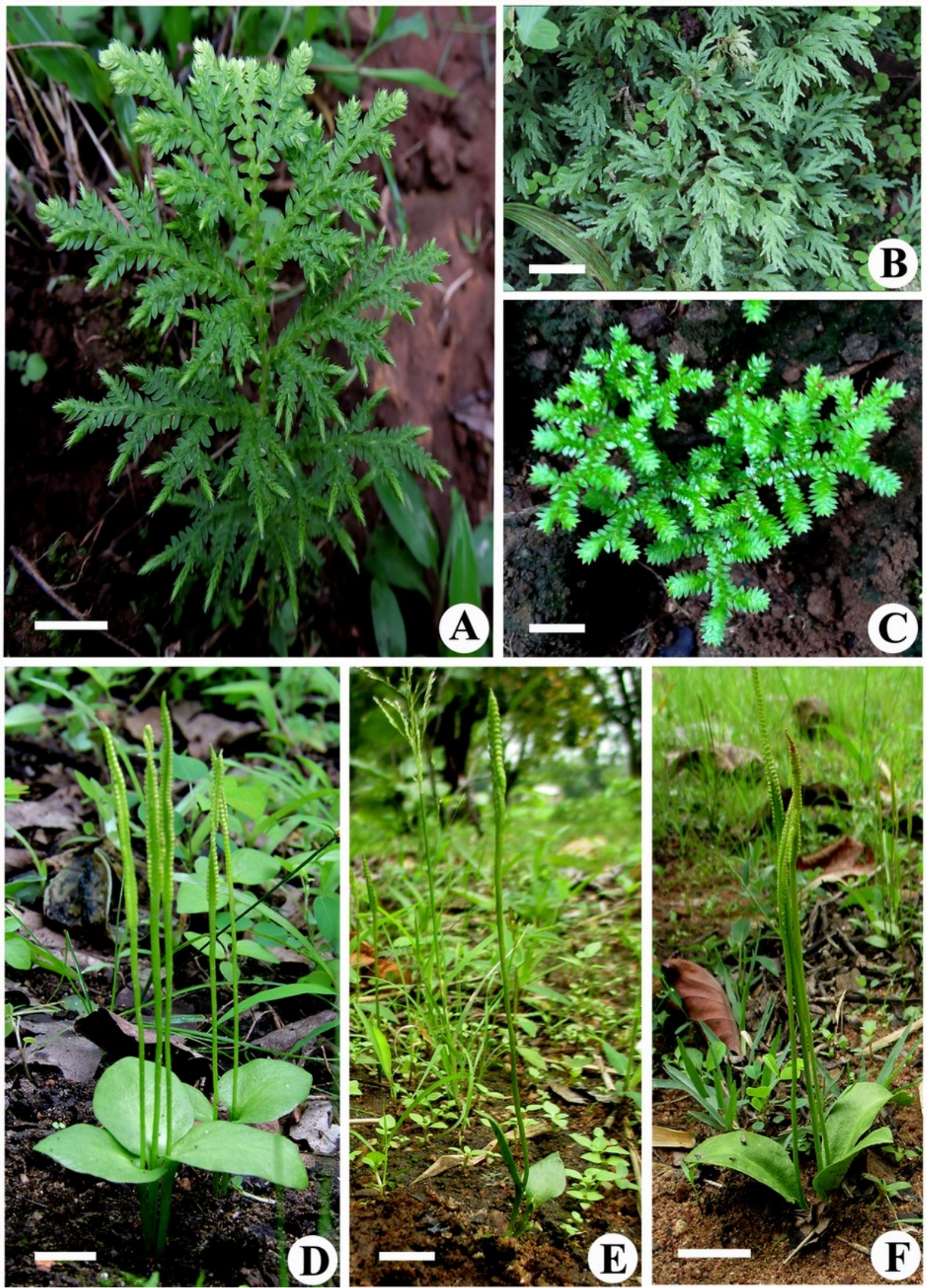

Fig. 1. Pteridophytes collected from different regions of Gujarat. A. Selaginella delicatula (Habit); B. Selaginella repanda (Habit); C. Selaginella ciliaris (Habit); D. Ophioglossum reticulatum (Habit); E. Ophioglossum nudicaule (Habit); F. Ophioglossum costatum (Habit). Scale bar: A, C, D, E, F = $10 \mathrm{~mm}, \mathrm{~B}=2 \mathrm{~cm}$

and Tectaria coadunata fall under EN. In contrast, $E$. debile is treated under regionally extinct in the wild (REW) since it is not found at the reported locality. For this purpose, we discussed with field taxonomist as well as local residents of that area from where Chavan and Padate (1962) and Padate (1969) collected E. debile and found that it is not available in wild.

In conclusion, studies on pteridophyte diversity in Gujarat state are completely neglected 

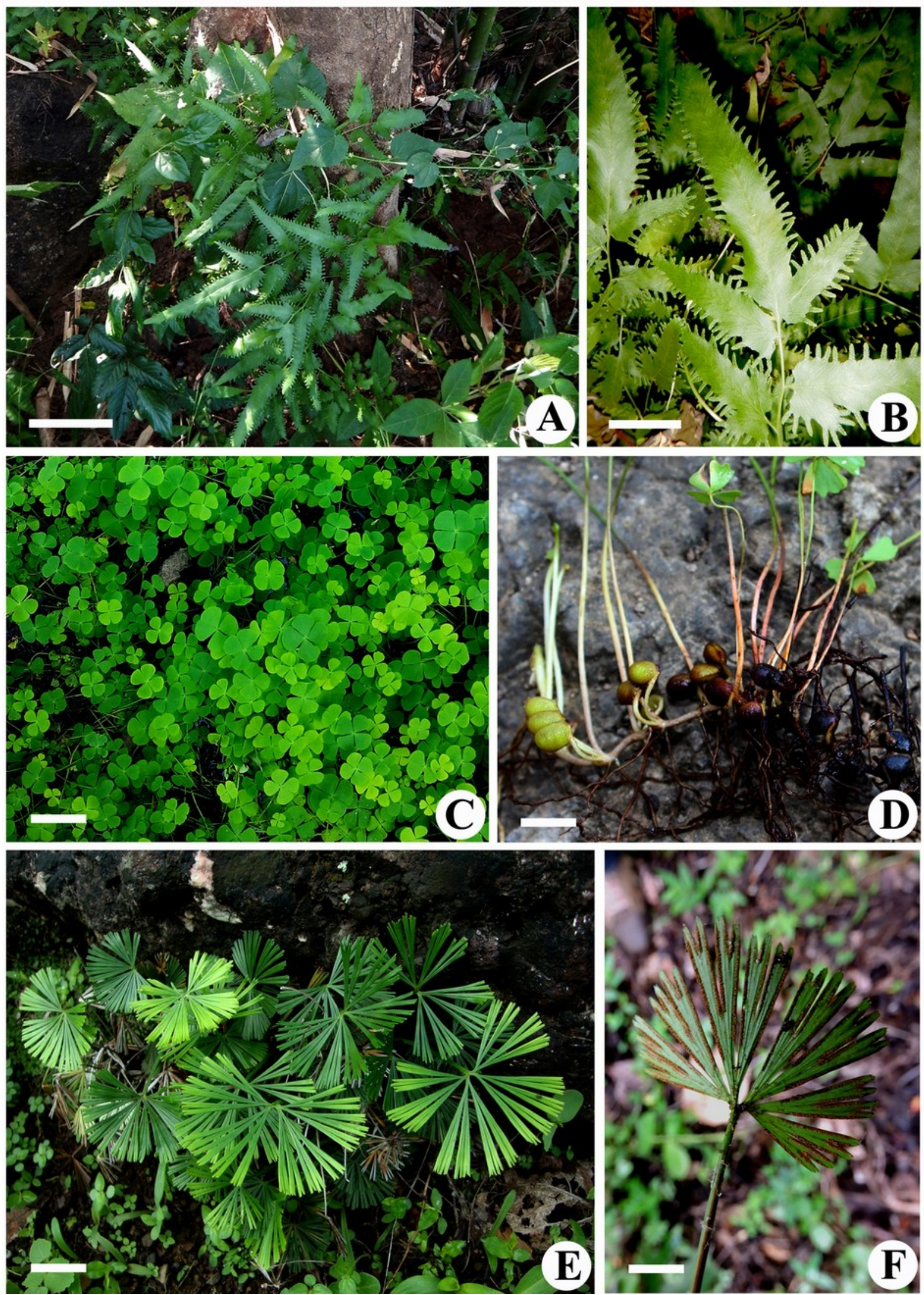

Fig. 2. Pteridophytes collected from different regions of Gujarat. A. Lygodium flexuosum (Habit); B. Lygodium flexuosum (Enlarged view of fertile branch); C. Marsilea minuta (Habit); D. Marsilea minuta (Enlarged view with sporocarp); E. Actiniopteris radiata (Habit); F. Actiniopteris radiata (Enlarged view of fertile portion). Scale bar: $A=35 \mathrm{~mm}, B=20 \mathrm{~mm}, C=15 \mathrm{~mm}, D=10 \mathrm{~mm}, E=13 \mathrm{~mm}, F=10 \mathrm{~mm}$.

since last four decades. However, present survey reported 23 species of pteridophyte from which eight species are reported for the first time which indicates that Gujarat state is rich in pteridophyte diversity and we expect much more number of species in further studies. From the earlier reported pteridophytes, $E$. debile is lost in the wild (REW) while I. coromandeliana lost its original 


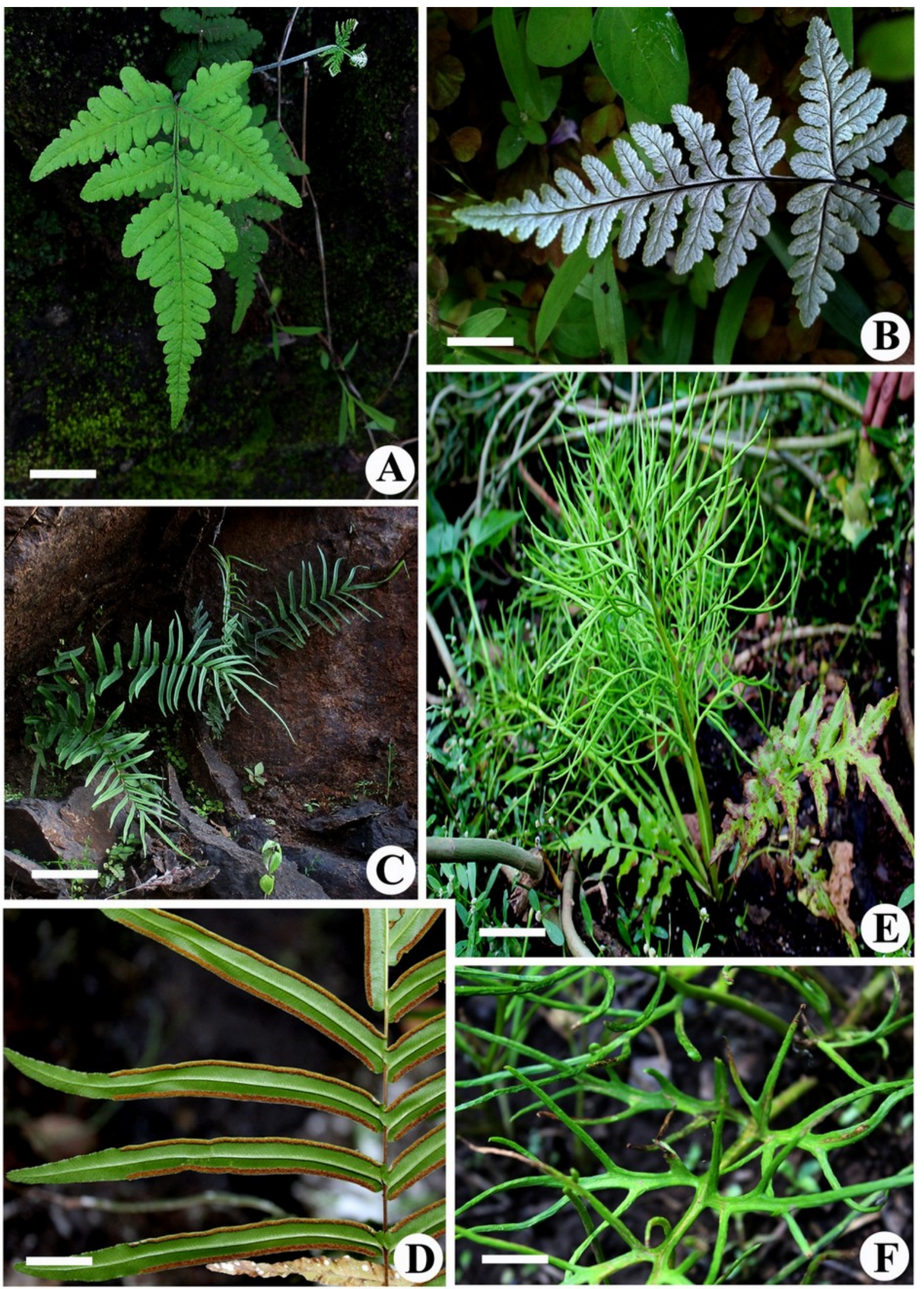

Fig. 3. Pteridophytes collected from different regions of Gujarat. A. Aleuritopteris bicolor (Habit: adaxial View); B. Aleuritopteris bicolor (Habit: abaxial View); C. Pteris vittata (Habit); D. Pteris vittata (Enlarged view of fertile pinnae); E. Ceratopteris thalictroides (Habit); F. Ceratopteris thalictroides (Enlarged view of fertile portion). Scale bar: $A=20 \mathrm{~mm}, B=12 \mathrm{~mm}, C=150 \mathrm{~mm}, D=10 \mathrm{~mm}, \mathrm{E}=75 \mathrm{~mm}, \mathrm{~F}=10 \mathrm{~mm}$

habit but reported from the new home at Talod, and Vaktapur in Gandhinagar district. At both these localities, population is less than 100 plants at each location. Increasing urbanisation, industrial areas, development of infrastructural facilities including rain water harvesting programmes by deepening of natural ponds, widening of roads, land sliding on road sides, 

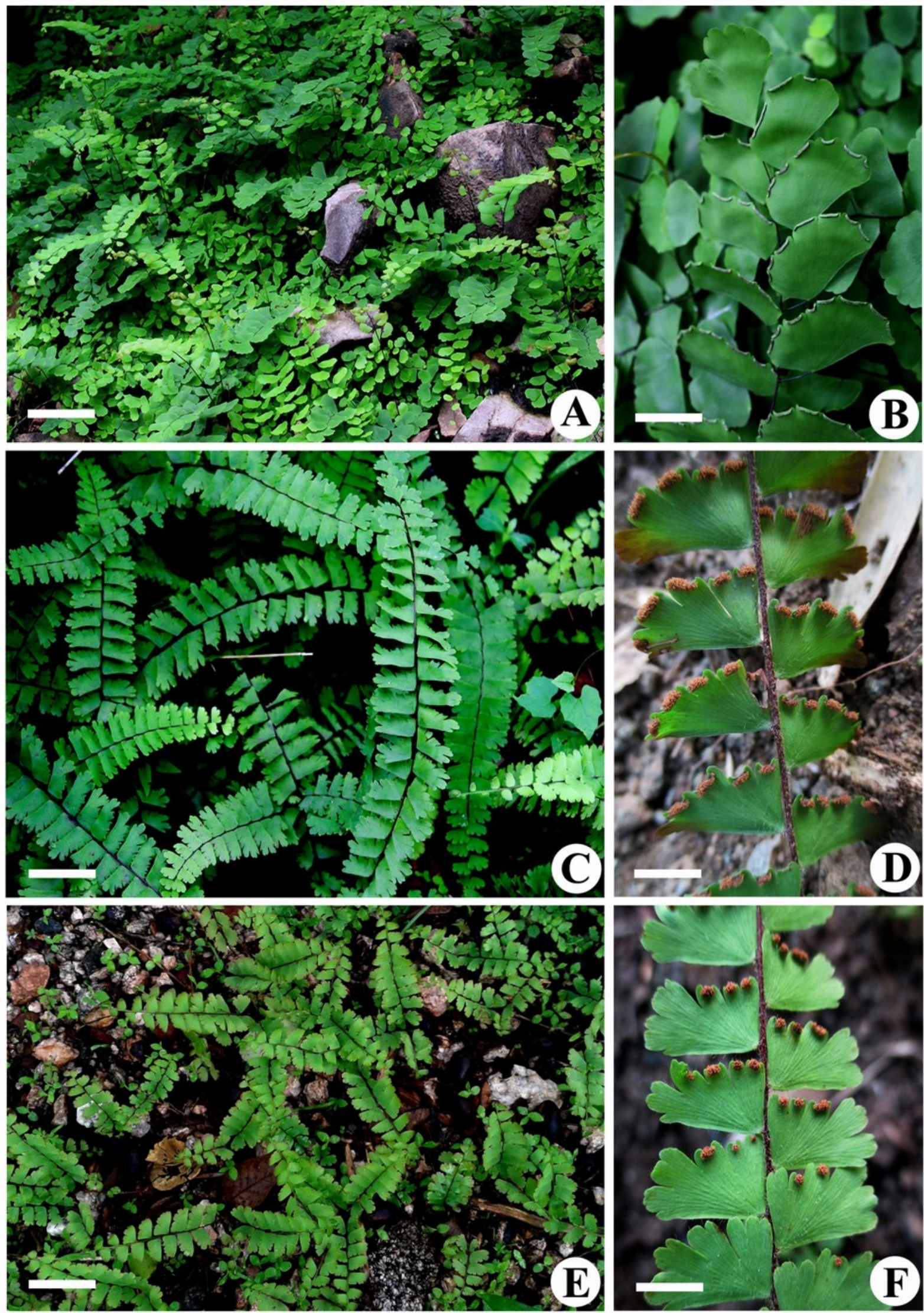

Fig. 4. Pteridophytes collected from different regions of Gujarat. A. Adiantum philippense (Habit); B. A. philippense (Enlarged view of fertile pinnae); C. Adiantum caudatum (Habit); D. A. caudatum (Enlarged view of fertile pinnae); E. Adiantum incisum (Habit); F. A. incisum (Enlarged view of fertile portion). Scale bar: A = $250 \mathrm{~mm}, \mathrm{~B}=25 \mathrm{~mm}, \mathrm{C}=40 \mathrm{~mm}, \mathrm{D}=10 \mathrm{~mm}, \mathrm{E}=75 \mathrm{~mm}, \mathrm{~F}=10 \mathrm{~mm}$

decreasing forest areas and increasing grazing areas etc. are the major threats to declining pteridophyte diversity of the state. Since, there is no enough information on the pteridophyte diversity of the Gujarat; thus, no much effort is made to conserve their diversity. Therefore, for 

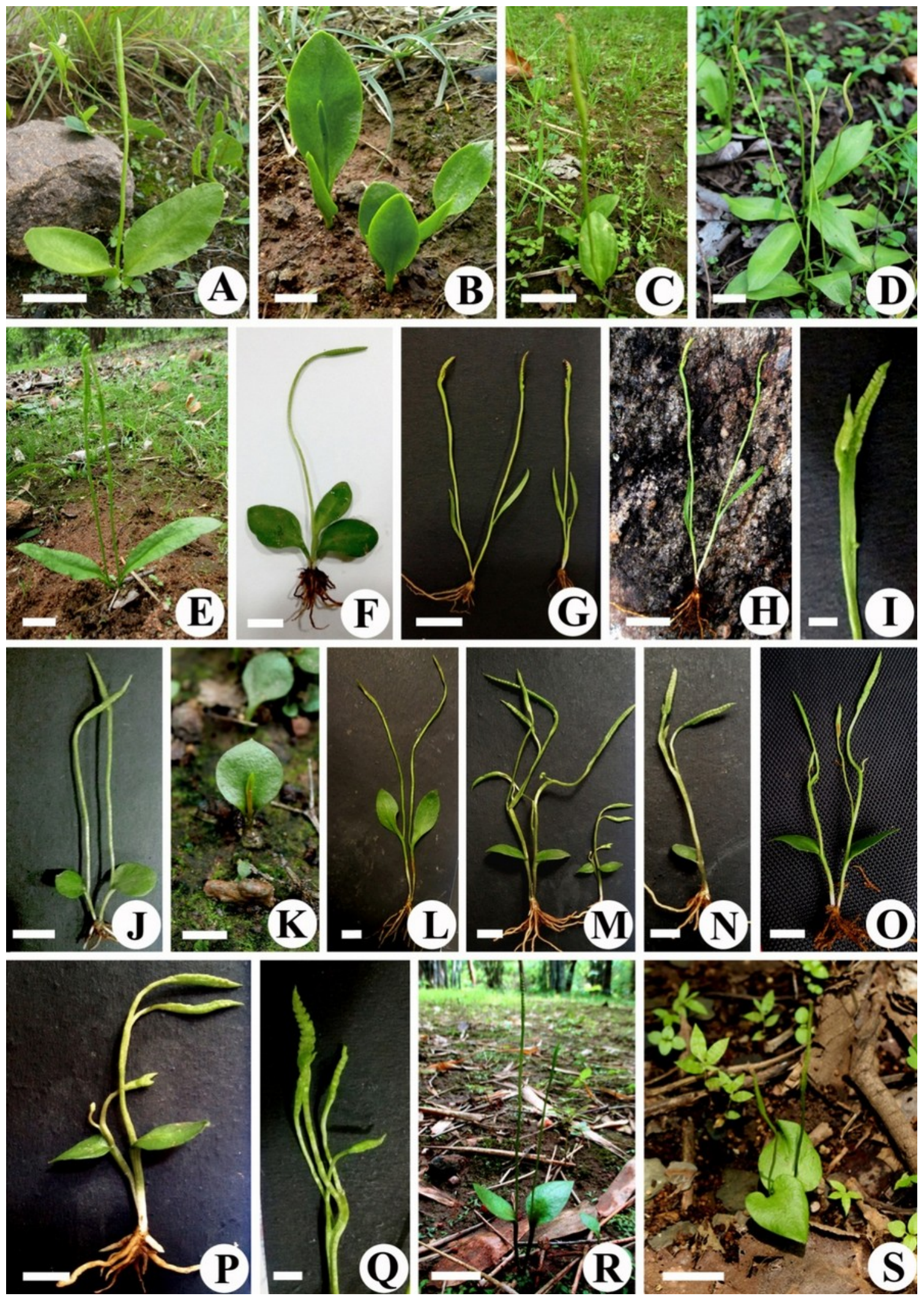

Fig. 5. Biotypes and anomalies in external morphology of Ophioglossum species (A-F Ophioglossum costatum, G-I O. gramineum, J-Q $O$. nudicaule, $\mathrm{R}$ and S O. reticulatum). A. Ophioglossum costatum (normal); B. $O$. costatum (feebly developed spike); C. O. costatum (normal, single tropophyll); D. O. costatum (normal, four elliptic lanceolate tropophyll); E. O. costatum (normal, two elliptic lanceolate tropophyll); F. O. costatum (normal, orbicular tropophyll); G, H and I. O. gramineum (bifurcated spike); J. O. nudicaule (normal, orbicular tropophyll); K. O. nudicaule (feebly developed spike and orbicular tropophyll); L. O. nudicaule (ovate tropophyll); M, N, O, P and Q. O. nudicaule (Branched and forked spike); R. O. reticulatum (normal); S. $O$. reticulatum (cordate tropophyll). Scale bar: A, G, H, J, K, M = $15 \mathrm{~mm}, \mathrm{~B}=5 \mathrm{~mm}, \mathrm{C}, \mathrm{D}, \mathrm{E}, \mathrm{R}=20 \mathrm{~mm}, \mathrm{~F}, \mathrm{~L}, \mathrm{~N}, \mathrm{O}$, $P, Q=10 \mathrm{~mm}, \mathrm{I}=3 \mathrm{~mm}, \mathrm{~S}=25 \mathrm{~mm}$

their conservation in natural habitat, there is an urgent need of in situ conservation by protecting the natural habitat by developing action plans. For this purpose help is also needed from government 
side particularly from the forest department to formulate necessary action plan to conserve these species by legal protection to protect the species falling in RET category. On this line, we have started ex situ conservation of these species by multiplying them using conventional method and cultivating them in the university arboretum. We are also trying to conserve them by providing the saplings to individuals who are interested to cultivate ferns in their home garden or as an indoor plant.

\section{Competing Interest}

The authors declare that they have no competing interests.

\section{Authors' contributions}

KSR and VMR designed and coordinated the study. RNK, SKP and KSR carried out fieldwork. Data analysis, identification and manuscript preparation is done by RNK and KSR.

\section{Acknowledgements}

Authors are thankful to the Gujarat Biodiversity Board, Gandhinagar for the financial assistance. Thanks are also due to anonymous reviewers for the suggestion on the previous version of the manuscript.

\section{References}

Anonymous, 2003-2015. www.thefreedictionary.com/biotype

Beddome, R. H. 1883. Handbook to the Ferns of British India, Ceylon and the Malay Peninsula, Thacker Spink \& Co., Calcutta. 501 pp.

Blatter, E. and J. E. d'Almeida. 1922. The Ferns of Bombay. D B Taraporevala Sons and Co., Bombay. $228 \mathrm{pp}$.

Bower, F. O. 1923. The Ferns. Vol. I, Cambridge University Press.

Bower, F. O. 1963. The ferns (Filicales). Vol. I-III Reprint edn. Today and Tomorrow's Book Agency, New Delhi.

Bridson, G. D. R. and L. Forman. (1992). The Herbarium Handbook. Kew.

Chandra, S. 2000. The Ferns of India (Enumeration Synonyms \& Distribution), International Book Distributors, Dehra Dun. 459 pp.

Chandra, S., C. R. Fraser-Jenkins, A. Kumari and A. Srivastava. 2008. A summary of the status of Threatened Pteridophytes of India. Taiwania 53(2): 170-209.

Chavan, A. R. and A. R. Mehta. 1956. Occurrence of Ophioglossum gramineum Willd in Gujarat. Science and Culture 21: 538-540.

Chavan, A. R. and S. N. Padate. 1962. The Hydrophytes of Savali Taluka. J. M. S. University of Baroda XI (3): 63-78.

Chavan, A. R. and S. N. Padate. 1963. Occurrence and Distribution of Ceratopteris thalictroides (Linn.) Brongn, in Gujarat State (India). J. M. S. University of Baroda XII: 5-6.
Chavan, A. R. and S. D. Sabnis. 1961. A study of the hydrophytes of Baroda and Environs. J. Indian Bot. Soc. XL(1): 121-130.

Dabgar, P. J. 2012. A contribution to the flora of Wadhvana wetland, Dabhoi Taluka (Gujarat) India. Bioscience Discovery 3(2): 218 -221.

Dixit, R. D. 1984. A Census of the Indian Pteridophytes Flora of India series IV. Botanical Survey of India (Howrah). $177 \mathrm{pp}$.

Dixit, R. D. 2000. Conspectus of Pteridophytic diversity in India. Indian Fern J. 17: 77-91.

Dudani, S. N., M. D. S. Chandran, M. K. Mahesh and T. V. Ramachandra. 2011. Diversity of Pteridophytes of Western Ghats. Sahyadri Issue-33.

Dudani, S. N., M. K. Mahesh, M. D. S. Chandran and T. V. Ramchandra. 2014. Pteridophyte diversity in wet evergreen forests of Sakleshpur in Central Western Ghats. Indian J. Plant Sci. 3: 28-39.

Fraser-Jenkins, C. R. 2008. Taxonomic Revision of Three Hundred Indian Subcontinental Pteridophytes with a Revised Census-List. Bishen Singh Mahendra Pal Singh, Dehra Dun. 685 pp.

Fraser-Jenkins, C. R. 2009. A brief comparison of modern pteridophyte classifications (families and genera in India). Indian Fern J. 26: 107-126.

Fraser-Jenkins, C. R. 2012. Rare and Threatened Pteridophytes of Asia 2. Endangered Species of India the Higher IUCN Categories. Bull. Natl. Mus. Nat. Sci., Ser. B 38(4): 153-181.

Fraser-Jenkins, C. R., D. R. Kandel and S. Pariyar. 2015. Ferns and fern-allies of Nepal Vol-1. National Herbarium and Plant Laboratories Department of Plant Resources, Kathmandu, Nepal. 492 pp.

Gaekwad, L. K. and Y. S. Deshmukh. 1956. Occurrence of Isoetes at Baroda in Gujarat from Bombay State. Science and Culture 22: 346.

GEC, (Gujarat Ecological Commission). 1996. Biological diversity of Gujarat: Current knowledge. Technical report, GERI Campus, Gandhinagar, Gujarat.

Ghosh, S. R., B. Ghosh, A. Biswas and A. K. Ghosh. 2004. The Pteridophytic flora of Eastern India Vol-1. Botanical Survey of India (Kolkata). $591 \mathrm{pp.}$

Goswami, H. K. 2007. Biology of Ophioglossum L. Bionature 27(1\&2): 1-73.

Inamdar, J. A. and J. J. Shah. 1967. Occurrence of Ophioglossum nudicaule L.f. and Ophioglossum nudicaule var. macrorrhizum (Kze.) Clausen in Dharampur Forest. Indian Forester 93(2): 95-97.

Inamdar, J. A. 1970. Development of Stomata in some Ophioglossum species. Ann. Bot. 34:975-981.

IUCN, 2001, 2012, 2016. Guidelines for Using the IUCN Red List Categories and Criteria. Ver. 12. Prepared by the Standards and Petitions Subcommittee. 500pp. www.iucnredlist.org/documents/RedListGuidelines.pdf.

Kachhiyapatel, R. N., A. P. Singh, V. M. Raole, and K. S. Rajput. 2015. Distribution and occurrence of some pteridophytes in Gujarat: a new record for the state. J. of Indian Bot. Soc. 94(3\&4): 236-244.

Kavitha, C., G. Manoj and K. Murugan. 2015. Diversity of pteridophytes of Ponmudi hills. IJBPAS 4(10): 6180-6190.

Kholia, B. S. 2014. Ferns and Fern-allies of Sikkim, A pictorial hand book part-2. Botanical Survey of India (Kolkata). 291pp. 
Khullar, S. P. 1994, 2000. An Illustrated Fern Flora of Western Himalaya Vols 1 \& 2. International Book Distributors, Dehra Dun.

Mahabale, T. S. 1948. Prothalli of Ceratopteris thalictroides (Linn.) Brongn. Bot. Gaz. 109:349-354.

Mahabale, T. S. 1963. Cultural Behaviour of Prothalli of Stenchlaena palustris, Ceratopteris thalictroides and Athyrium hohenackerianumi. Plant and Organ Culture, Symp. Published Int. Soc. Plant Morphol. 382-289. doi: $10.1086 / 335486$

Modi, N. R. and S. N. Dudani. 2013. Biodiversity Conservation through Urban Green Spaces: A Case Study of Gujarat University Campus in Ahmedabad. Intl. J.Conser. Sci. 4:189-196.

Modi, N. R. 2015. Preliminary record of pteridophytes of Gujarat. In: Next generation Pteridology, International Conference on Lycophyte and Fern Research. Smithsonian Institute and United State Botanic Garden, 1-5 June 2015, Washington DC, p 1011.

Moran, R. C. 2008. Diversity, biogeography, and floristics. Biology and evolution of ferns and lycophytes. Cambridge University Press, New York. 480pp.

Nayar, B. K. and S. Devi. 1964. Spore Morphology of Indian Ferns I. Aspidiaceae, Grana Palynologica. 5:1, 80120. doi: $10.1080 / 00173136409429131$

Padate, S. N. 1969. A Contribution to the flora of Savli taluka, Gujarat state, India. The J. M. S. University of Baroda XVII(3): 101-112.

Panigrahi, G. and R. D. Dixit. 1967. Studies in Indian Pteridophytes. IV. The family Ophioglosaaceae in India. Botanical Survey of India 35: 230-266.

Patel, R. S., K. C. Patel, N. B. Patel, K. Patel, R. B Shah and H. Joshi. 2010. Floristic survey of campus of Art. Com. \& Sci. College, Borsad (Gujarat), India. Plant Archives 10(1): 293-297.

Patel, S. K., R. N. Kachhiyapatel, A. P. Singh, and K. S. Rajput. 2015. Status of Isoetes coromandeliana L.f. and Equisetum debile Roxb. Ex Voucher in Gujarat State, Western India. Notulae Scientia Biologicae 7(4): 441.
Patil, S. and M. Dongare. 2013. Adiantum tenerum Swartz (Adiantaceae- Pteridophyta): A new distribution record for India. Indian Fern J. 30: 115-118.

Patil, S., R. Mahamuni and M. Dongare. 2012. Diversity of ferns in the hills of northern Western Ghats, Maharashtra, India. Indian Fern J. 29: 158-163

Patil, S.M., P. R. Hande and M. Dongare. 2014. A filmy fern: Crepidomanes latealatum (Bosch) Copel. New to northern Western Ghats of India. Indian Forester 140(9): 939-940

Patil, S., R. Lavate, V. Rawat and M. Dongare, 2016. Diversity and distribution of Pteridophytes from Satara District, Maharashtra (India). Plant Science Today 3(2), 149-156. doi: 10.14719/pst.2016.3.2.216

Phatak, V. G., L. K. Gaekwad and Y. S. Deshmukh. 1953. Ophioglossum from Baroda occurrence and teratology. J. M. S. University of Baroda II: 135141.

Rajput, K. S., R. N. Kachhiyapatel, V. M. Raole and A. P. Singh. 2016. Relocation of Ophioglossum gramineum Willd (Ophioglossaceae). Current Science 111(2): 243.

Sanjappa, M. and P. Venu. 2010. An overview of Biodiversity status trends and threats. BSI, Howrah. p. 18-19.

Saxton, W. T. and L. J. Sedgwick. 1918. Plants of northern Gujarat. Rec. Bot. Survey, India 6: 221223.

Shah, J. J. and B. S. Vaidya. 1964. Occurrence of Ophioglossum in Dangs forests. Vidya 7: 92-95.

Smith, A. R., K. M. Pryer, E. Schuettpelz, P. Korall, H. Schneider and P. G. Wolf. 2006. A classification for extant ferns. Taxon 55: 705-731. doi: $10.2307 / 25065646$

Sukumaran, S., S. Jeeva and A. D. S. Raj. 2009. Diversity of pteridophytes in miniature sacred forests of Kanyakumari district, southern Western Ghats. Indian Journal of Forestry 32(3): 285-290. 